\title{
Effect of Gamma Irradiation on Angiotensin Converting Enzyme Inhibition, Antioxidant Activity, Total Phenolic Compound and Total Flavonoid of Peperomia pellucida Herbs Extract
}

\author{
Anies Monica Adhitia, Alisa Nur Octaviani, Rissyelly, Katrin Basah, Abdul Mun'im*
}

Anies Monica Adhitia, Alisa Nur Octaviani, Rissyelly, Katrin Basah, Abdul Mun'im*

Department of PharmacognosyPhytochemistry, Faculty of Pharmacy, Universitas Indonesia, Kampus Baru UI Depok 16424, Depok, INDONESIA.

\section{Correspondence}

Abdul Mun'im

Department of Pharmacognosy-Phytochemistry, Faculty of Pharmacy, Universitas Indonesia, Kampus Baru UI Depok 16424, Depok, INDONESIA.

Ph no: +62 217270031

Email: munimabdoel@gmail.com.

\section{History}

- Submission Date: 21-12-2016;

- Review completed:05-01-2017

- Accepted Date: 11-01-2017.

DOI : 10.5530/pj.2017.2.41

Article Available online

http://www.phcogj.com/v9/i2

\section{Copyright}

(c) 2017 Phcog.Net. This is an openaccess article distributed under the terms of the Creative Commons Attribution 4.0 International license.

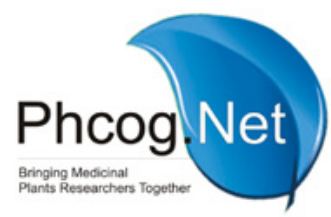

\begin{abstract}
Introduction: Peperomia pellucida L. Kunth has been reported to have some biological activities such as antihypertensive and antioxidants. Herbal materials susceptible to contamination during processing and storage which can shortens their shelf life. Gamma-irradiation has been used as a method for preservation. Methods: This research aimed to analyze the effect of gamma-irradiation on inhibition activity of angiotensin converting enzyme (ACE), antioxidant activity, total phenol content, total flavonoid, and thin layer chromatography profiles of P. pellucida L. Herbs extract. The extract was irradiated with $60 \mathrm{Co}$ gamma rays at $2.5 ; 5 ; 7.5$; dan $10 \mathrm{kGy}$. Results: Irradiation up to $10 \mathrm{kGy}$ did not change ACE inhibitory activity and TLC profile. No significant differences were noted in the inhibition activity of ACE and the type of chromatogram profiles between non-irradiated extract and irradiated extracts up to a dose of $10 \mathrm{kGy}$ while total flavonoids showed a significant decrease. In addition, total phenolic content and antioxidant activity showed a significant increase of extracts were irradiated up to 5 kGy and decrease at dose 7,5 kGy and 10 kGy. Gamma-irradiation up to $10 \mathrm{kGy}$ didn't affect the activity of ACEinhibitor in-vitro while significant difference $(P<0.05)$ of antioxidant activity, total flavonoids and phenolic content of the extract $P$. Pellucida. Conclusion: In conclusion, gamma - irradiation can be used as a preservation method for ethanol extract P. Pellucida L. Kunth herbs.
\end{abstract}

Key words: ACE, Antioxidant, Extract, Gamma-irradiation, Peperomia pellucida, Total flavonoids, Total phenolic.

\section{INTRODUCTION}

Herbs are prone to contamination by microorganisms and insect pests, that could occur either during preharvest processing or storage. This shortens their shelf life as well as in rare cases cause major illness. ${ }^{1}$ Several reports have demonstrated that gamma irradiation method on herbal medicines is an effective method for decontamination, quarantine barriers in international trade and for improving shelf life due to its efficiency and high penetration. ${ }^{2,3}$ Gamma rays are a type of electromagnetic radiation which originates within the nucleus of a radioisotope. Irradiation facilities generally use the radionuclide cobalt-60 as the source of gamma rays. The energy threshold for inducing radioactivity in herbs is $5 \mathrm{MeV}$ for gamma sources. Therefore, the energy of gamma rays from cobalt-60 (1.17 MeV and $1.33 \mathrm{MeV})$ is not sufficient to generate radioactive substances in medicinal plants. ${ }^{3}$ Gamma ray irradiation up to $10 \mathrm{kGy}$ dose did not affect the biological activity of the methanol extract of Schizandra chinensis. ${ }^{4}$ Results of other studies have also known that exposure to gamma - irradiation up to a dose of $10 \mathrm{kGy}$ in $70 \%$ ethanol extract of leaves of Nelumbo nucifera is not a significant effect on antioxidant activity and total polyphenol compounds. ${ }^{5}$ Likewise with Lee, Lee, Bai, Choi, Kim, and Chung (2013) who argued that there was no significant difference in tyrosinase inhibitory activity of the metha- nol extract Eremochloa ophiuroides Munro irradiated gamma rays up to a dose of $10 \mathrm{kGy} .{ }^{6}$ Peperomia pellucida is reported to have a wide range of biological activities. These are antioxidant, antimicrobial, anticancer, analgesic, anti-inflammatory, and antihypertensive activities. ${ }^{711}$ The ethanolic extract of the plan has antihypertensive activity through inhibition of the angiotensin-converting enzyme (ACE) in vitro with $\mathrm{EC}_{50}$ value of $7.17 \mathrm{mg} / \mathrm{mL}$ were compared with captopril (13.68 pg/ mL). ${ }^{11}$ Irradiation can influence the levels of phytochemicals depending on the applied dose, moisture of material, exposure time, and the sensitivity of the phytochemicals towards irradiation and the nature of the raw material used. Therefore monitoring both qualitative and quantitative changes in bioactive phytochemicals after irradiation and storage is of importance. ${ }^{1,12}$ So this study aimed to analyze the effect of gamma-ray irradiation on the ethanol extract of P. Pellucida herbs in order to eliminate contamination, without causing a decrease in its activity as ACE inhibitors.

\section{MATERIALS AND METHODS}

\section{Materials}

The aerial part of Peperomia pellucida L. Kunth. were collected from West Java, Indonesia. The species was identified and authenticated by the Indone- 
sian Institute of Sciences, Bogor, Indonesia, voucher specimen number 8-594/IPH.3./KS/II/2016, angiotensin converting enzyme (ACE) KitWST test kit (Dojindo laboratories, Japan), Ethanol, quercetin, 2,2-diphenyl-1-picrylhydrazyl, sodium acetate and Folin-Ciocalteu reagent (Sigma-Aldrich), gallic acid, sodium carbonate and aluminium chloride, toluene, dichlormethane and methanol (Merck), and captopril (Kimia Farma Ltd, Indonesia).

\section{Sample Preparation}

Dried powder was sorted out to separate them from pollutants, blended, then were put through a 25 mesh sieve.

\section{Water Determination}

Determination of moisture content was done with toluene distillation method.

\section{Gamma Irradiation}

Ethanolic extract of the herbs P. pellucida L. Kunth was divided into two sets. One set was kept as a non-irradiated sample. The other set of samples, packed in a vial sealed with alumunium cap were irradiated in a gamma chamber with a cobalt-60 source to doses of 2.5, 5, 7.5 and $10 \mathrm{kGy}$ at the dose rate of $6.01 \mathrm{kGy} / \mathrm{h}$. Irradiated and non-irradiated samples were stored under ambient conditions. Irradiation was done at Atomic and Nuclear National Bureau, Jakarta.

\section{Plant Extraction}

The dried powder was extracted after irradiation process by reflux using 70\% ethanol (1:10) for 45 minutes and the procedure was repeated 3 times. All filtrates were combined and concentrated using a rotary vacuum evaporator at $40^{\circ} \mathrm{C}$, then dried using oven vacuum at $50^{\circ} \mathrm{C}$.

\section{Free Radical-Scavenging Assay with DPPH}

Various concentration of samples was prepared by dissolving the extract using methanol. About $1 \mathrm{~mL}$ of each concentration was put in a test tube, added $1 \mathrm{~mL}$ of $100 \mathrm{ppm}$ DPPH solution and $2 \mathrm{~mL}$ of methanol pa. The mixture was vortexed for 20 seconds and incubated at $37^{\circ} \mathrm{C}$ for $30 \mathrm{~min}$ utes. The absorbance of each concentration was measured with Uv-Vis spectrophotometer at $515 \mathrm{~nm}$. Quercetin was used as the standard.

\section{ACE Inhibitory Activity Assay}

Both types of extract (irradiated and non-irradiated) were subjected to ACE-inhibitory assay using Dojindo ACE Kit-WST. The enzymatic reaction was initiated by the ACE and aminoacylase in the mixture containing 3HB-GGG (3- hydroxybutyrate glycyl glycylglycine) and the ACEinhibitor. The yield of $3 \mathrm{HB}$ was monitored indirectly through formazan concentration, which was measured at $450 \mathrm{~nm}$ after 10 -minute reaction at $25^{\circ} \mathrm{C}$. Testing procedures were run according to the manufacturer's instructions using a 96-well plate without modification, and the inhibition rate was calculated based on a comparison of the optical absorbance of samples treated wells (s), control wells (Ac), and blank wells (Ab). Absorbance was measured at $450 \mathrm{~nm}$ using the microplate reader. Captopril was used as the standard.

\section{Determination of Total Phenolic Content}

Total phenolic content was determined using the Folin-Ciocalteu colorimetric methods. ${ }^{6}$ Different concentration of gallic acid (30-80 ppm) and sample (3000 ppm) were dissolved in methanol. About $200 \mu \mathrm{L}$ of each concentration was put into a test tube, and $1.5 \mathrm{~mL}$ Folin-Ciocalteu was added. All test tubes were incubated in a dark place at room temperature for 5 minutes. Then $1.5 \mathrm{~mL} 6 \% \mathrm{Na}_{2} \mathrm{CO}_{3}$ was added to each test tube and incubated for 105 minutes in a dark place at room temperature. The
$\%$ inhibitory $=\left[\frac{(\text { Ablank positive-A sample })}{(\text { Ablank positive-Ablank negative })}\right] \times 100 \%$

absorbance of each concentration was measured using UV-Vis spectrophotometer at $740 \mathrm{~nm}$.

\section{Determination of Total Flavonoid Content}

Determination of total flavonoid content was done using aluminium chloride colorimetric methods. ${ }^{7,8}$ Various concentration of quercetin (20 - $120 \mathrm{ppm}$ ) and sample (3000 ppm) were dissolved in methanol. About $0.5 \mathrm{~mL}$ of each concentration was taken in a test tube, added $1.5 \mathrm{~mL}$ methanol, $0.1 \mathrm{~mL} 10 \%$ aluminium chloride, $0.1 \mathrm{~mL}$ sodium acetate $(1 \mathrm{M})$ and $2.8 \mathrm{~mL}$ distillate water into each test tube. Then, the test tubes were incubated at room temperature for 30 minutes. The absorbance of each concentration was measured by Uv-Vis Spectrophotometer at $434 \mathrm{~nm}$.

\section{Thin Layer Chromatography Profile}

TLC profiles were performed using silica gel $60 \mathrm{~F}_{254}$ and dichlormethane: methanol $(92: 8)$. The extracts were made at $10000 \mathrm{ppm}$ and were spotted on the TLC plate for elusion. TLC was analyzed qualitatively under UV light of $254 \mathrm{~nm}$ and $366 \mathrm{~nm}$, also by qualitative densitometry using TLC Scanner 3 with Camag Wincats software.

\section{Statistical Analysis}

Data was analyzed using one-way ANOVA and a significant difference was determined by the Tukey test $(\alpha=0.05)$. Correlation between antioxidant activity, total phenolic compound, and total flavonoid compound was analyzed using Spearman test.

\section{RESULTS AND DISCUSSION}

\section{Water Content Determination}

Experiment determination of water content of the $70 \%$ ethanol extract of $P$. pellucida Kunth herbs obtained with a value of $14.66 \%$. Low water content can minimize the formation of free radicals $\mathrm{OH}^{\star}$ and $\mathrm{H}^{\star}$ from the radiolysis of water molecules in the samples irradiated gamma ray. ${ }^{13}$

\section{Total Plate Count (TPC)}

Table 1 showed effect of gamma irradiation on TPC. TPC of the herb extract showed a decrease of microbial growth in all irradiated samples. Absorbed dose of dried herbs $1 \mathrm{kGy}$ to eliminate insects, and $10 \mathrm{kGy}$ to eliminate pathogenic microorganisms. Gamma irradiation can kill bacteria by destroying DNA of bacteria, therefore, obstructing bacteria division. ${ }^{14}$

Table 1: TPC of suruhan herb extract

\begin{tabular}{ccc}
\hline No & Irradiation (kGy) & TPC (Colony/g) \\
\hline 1 & 0 & 585 \\
2 & 2.5 & 290 \\
3 & 5 & $<10$ \\
4 & 7.5 & $<10$ \\
5 & 10 & $<10$ \\
\hline
\end{tabular}

\section{Extraction yields}

Extraction yield of non-irradiated and irradiated samples ranged from $21.16-24.86 \%$. Ethanol was used because of its non-toxic characteristic and is permitted to be used by the department of health of the Republic of Indonesia. 


\section{Free radical scavenging assay with DPPH}

Antioxidant activity is shown in $\mathrm{EC}_{50}$ value as a percentage of inhibition of free radicals. During a test, the purple DPPH radical reduced by antioxidants / reducing compounds (antioxidants hydrogen donor) into pale yellow hydrazine. DPPH radical reactions and antioxidant occur where antioxidants $(\mathrm{AH})$ is the donor molecule and $\mathrm{A}$. is a product of free radicals. ${ }^{15}$ Table 2 showed effect of gamma irradiation on DPPH radical scavenging activity.

Based on non-parametric data analysis, it is known that there were no significant changes in the dose of $2.5 \mathrm{kGy}$ and $5 \mathrm{kGy}$ compared with non-irradiated samples, but at a dose of $7.5 \mathrm{kGy}$ and $10 \mathrm{kGy}$ significant changes marked by the increase in $\mathrm{EC}_{50}$ compared with non-irradiated samples.

\section{ACE Inhibitory Activity}

ACE inhibitory activity of captopril at ppm was $34.42 \%$ and all ethanol extracts were measured at $100 \mathrm{ppm}$, giving results shown in Table 3 . The data obtained shows there were no significant differences between non-irradiated and radiation processed samples. Having an increasing the value of percent inhibition was possible due to the increased phenolic content could be attributed to the release of phenolic compounds from glycosidic components and the degradation of larger phenolic compounds into smaller ones by gamma irradiation. Having the lease decrease was the $10 \mathrm{kGy}$ irradiated sample, was possible due to ionization effects of irradiation. ${ }^{16}$ Gamma irradiation may also generate formation of free radicals which induce breakage of chemical bonds therefore, altering chemical structures or decomposition of phytochemicals which have an ACE inhibitory activity potential. ${ }^{17,18}$

\section{Total Phenolic Content}

The increase in total phenolic content can be caused by the release of phenolic compounds from glycosidic components and degradation of phenolic compounds. ${ }^{19}$ Free phenolic levels may depend on the balance between the release of some phenolic bond to form free and free phenolic degradation by gamma irradiation. Total phenolic content in irradiated and non-irradiated samples can be seen in Table 4 .

\section{Total Flavonoid Content}

Flavonoids are part of a group of phenolic compounds, which was mentioned earlier, a decrease of phenolic compounds due to gamma-ray irradiation caused by hydroxyl radicals formed from the interaction of gamma rays with the water contained in the sample resulting in hydroxylation reactions on the aromatic ring phenolic compounds and lead to termination of aromatic ring chain. The decrease levels of flavonoids was also allegedly caused by the loss of the aromatic ring of the phenolic compounds in the sample due to gamma irradiation..$^{20}$ Table 5 showed total flavonoid content of samples after irradiation.

\section{Thin Layer Chromatography (TLC) Profile}

TLC profiles of all samples on UV $254 \mathrm{~nm}$ and $366 \mathrm{~nm}$ were similar. Under $254 \mathrm{~nm}$, the non-irradiated sample gave 9 peaks which were also found in the irradiated samples. After spraying the TLC plate with $0.5 \%$ $\mathrm{AlCl}_{3}, 10$ spots had a change in color to yellowish and greenish (Figure 1). Figure 2 presented TLC densitogram of samples.

The difference of amounts peaks and spotting faded from the non-irradiated and irradiated samples may indicate the formation of a different substance caused by irradiation, gamma ray irradiation generates free radicals which are can cause hydroxylation or degradation of components in the samples. ${ }^{21}$ Furthermore, decrease meant or increase meant of peak areas of the irradiated samples is thought to be a result of degradation of components into another component. ${ }^{22}$ Colour change of the
Table 2: $\mathrm{EC}_{50}$ of irradiated and non-irradiated sample

\begin{tabular}{cc}
\hline Dose $(\mathrm{kGy})$ & $\mathrm{EC50}(\mu \mathrm{g} / \mathrm{mL})$ \\
\hline 0 & 210,09 \\
2,5 & 226,58 \\
5 & 210,30 \\
7,5 & $382,90^{*}$ \\
10 & $701,06^{*}$ \\
\hline
\end{tabular}

Table 3: ACE inhibitory activity of ethanol extracts of suruhan herb extract

\begin{tabular}{cc}
\hline Irradiation dose (kGy) & ACE inhibitory activity (\%) $n=3$ \\
\hline 0 & 53.97 \\
2.5 & 53.14 \\
5 & 50.87 \\
7.5 & 50.98 \\
10 & 46.33 \\
\hline
\end{tabular}

Table 4: Total phenolic content of irradiated and non-irradiated sample

\begin{tabular}{cc}
\hline Sample & Total Phenolic (mgGAE/g extract) \\
\hline Non-Irradiation & $19.59 \pm 0.24^{*}$ \\
2.5 kGy Sample & $20.72 \pm 0.21^{*}$ \\
5 kGy Sample & $21.86 \pm 0.39^{*}$ \\
7.5 kGy Sample & $17.53 \pm 0,69^{*}$ \\
10 kGy Sample & $13.71 \pm 0.40^{*}$ \\
\hline
\end{tabular}

Table 5: Data from a total flavonoid compound of the five samples

\begin{tabular}{cc}
\hline Sample & Total Flavonoid mgQE/g Extract \\
\hline Non-Irradiation & $19.60 \pm 0.28^{\star}$ \\
2.5 kGy Sample & $9.48 \pm 0.47^{*}$ \\
5 kGy Sample & $9.38 \pm 0.51^{\star}$ \\
7.5 kGy Sample & $16.29 \pm 0.89^{\star}$ \\
10 kGy Sample & $4.27 \pm 0.29^{*}$ \\
\hline
\end{tabular}

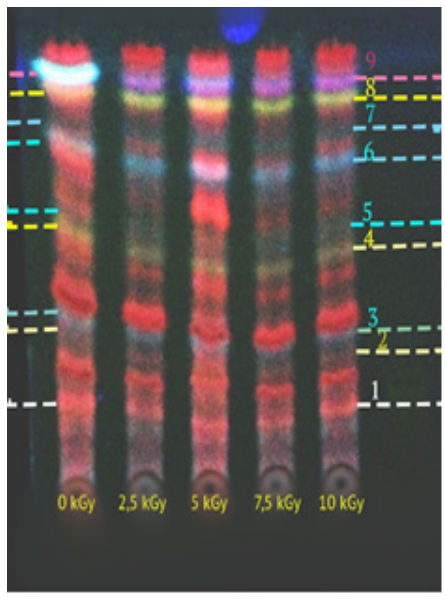

A

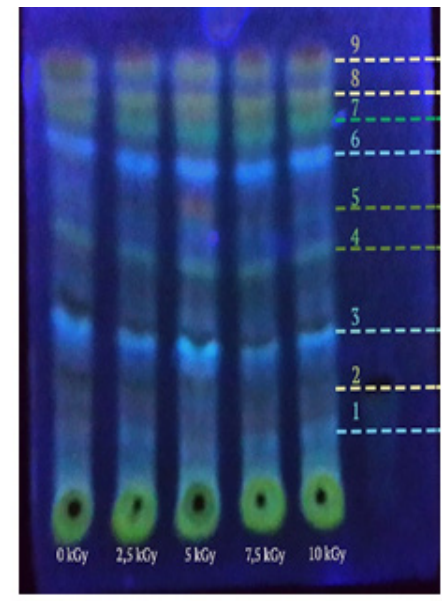

B
Figure 1:TLC profiles of the ethanolic extracts using Silica Gel $60 \mathrm{~F}_{254}$ and dichloromethane: methanol (92:8) under UV light before (A) and after (B) spraying with $\mathrm{AlCl}_{3} 5 \%$. 


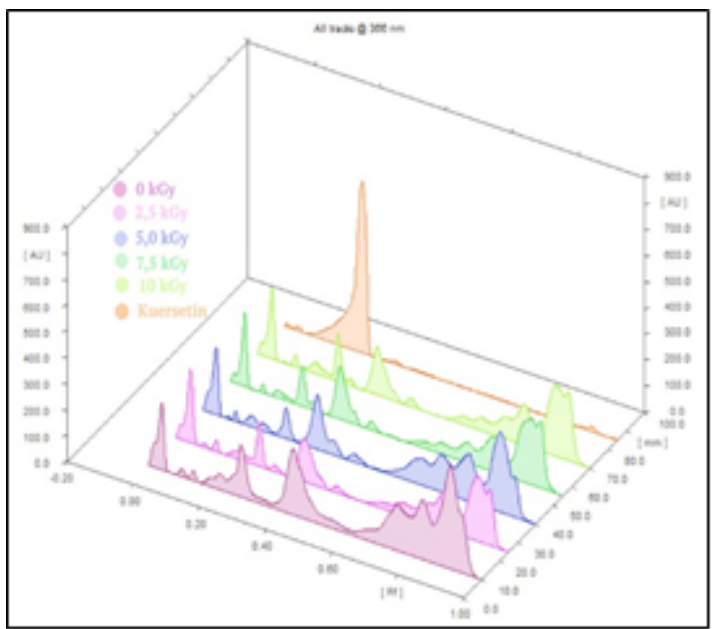

$366 \mathrm{~nm}$

Figure 2: TLC dencytogram of the samples under 366 dan $254 \mathrm{~nm}$.

spots' fluorescence after applying $0.5 \% \mathrm{AlCl}_{3}$ to greenish yellowish indicates the existence of flavonoids. ${ }^{23}$

\section{Correlation Analysis}

Based on this correlation test showed that the total phenol compound or the total flavonoid compound was negatively correlated with $\mathrm{EC}_{50}$ values, but positively correlated with antioxidant activity. Judging from the data results that the antioxidant activity and phenolic experienced a significant decrease in irradiation dose of $7.5 \mathrm{kGy}$ and $10 \mathrm{kGy}$. As was mentioned earlier that the decrease is thought to be caused by the presence of radicals formed by the interaction of gamma - irradiation with the water contained in the sample. It can be concluded that the compounds that have the antioxidant activity in the sample are phenolic compound.

\section{CONCLUSION}

No significant differences were noted in the inhibition activity of ACE between non-irradiated extract and irradiated extracts. The type of chromatogram profiles in irradiated extracts was similar to those of non-irradiated extract. Total phenolic and total flavonoid content didn't change significantly compare to control at dose $5 \mathrm{kGy}$ and $7.5 \mathrm{kGy}$. There's a correlation between antioxidant activity with total phenolic content but not with total flavonoid content. In conclusion, gamma ray irradiation can be used as a preservation method for ethanol extract of $P$. pellucida L. Kunth herbs.

\section{ACKNOWLEDGMENT}

This study was financially supported by Directorate of Research and Community Engagement, Universitas Indonesia via Hibah PITTA 2016.

\section{CONFLICT OF INTEREST}

None

\section{ABBREVIATION}

ACE: Angiotensin Converting Enzyme, DPPH: 1,1-Diphenyl-2-picrylhydrazyl.

\section{REFERENCE}

1. Chatterjee S, Kumar V, Khole S, Sanyal B, Murali T, Variyar P. Radiation processing: an effective quality control tool for hygienization and extending the shelf life of a herbal formulation, Amritamehari churnam, Journal of Radiation Research And Applied Sciences. 2015;30:1-10.

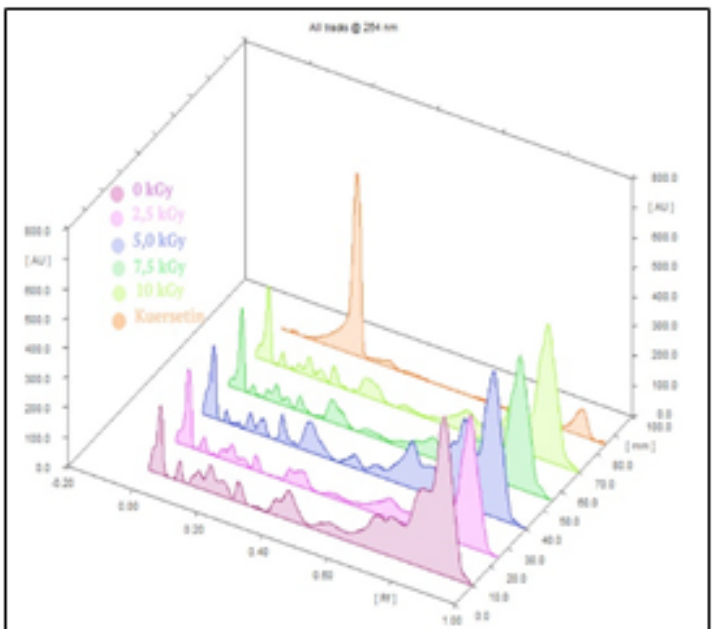

$254 \mathrm{~nm}$

2. Hong YH, Park JY, Park JH, Chung MS, Kwon KS, and Chung K. Inactivation of Enterobacter sakazakii, Bacillus cereus, and Salmonella typhimurium in powdered weaning food by electron-beam irradiation, Radiation Physics and Chemistry. 2008;77:1097-100. https://doi.org/10.1016/j.radphyschem.2008.05.004.

3. Thongphasuk $P$, Thongphasuk J. Effects of irradiation on active components of medicinal plants: A review. Rangsit Journal of Arts and Sciences. 2012;2(1):5771.

4. Lee S S, Lee E M, An C B, Kim T, Lee K S, Cho J, et al. Effects of irradiation on decolourisation and biological activity in Schizandra chinensis extracts, Food Chemistry. 2011;125:214-20 https://doi.org/10.1016/j.foodchem.2010.09.003.

5. Jeong YI, Lee HJ, Park YD, Jin CH, Choi DS, and Byun MW. Effects of gamma irradiation on total polyphenols, radical scavenging activities and decolourization of Nelumbo nucifera extracts. Radiation Physics and Chemistry. 2009;78:575-7. https://doi.org/10.1016/j.radphyschem.2009.03.076.

6. Lee E M, Lee S S, Bai H W, Cho J Y, Kim T H, Chung B Y. Effect of gamma ir radiation on the pigments and the biological activities of methanolic extracts from leaves of centipedegrass (Eremochloa ophiuroides Munro). Radiation Physics and Chemistry. 2013;91:108-13. https://doi.org/10.1016/j.radphyschem.2013.06.010

7. Wei L S, Wee W, Yong J, Siong F, Syamsumir D F. Characterization of Anticancer, Antimicrobial, Antioxidant Properties and Chemical Compositions of Peperomia pellucida Leaf Extract. 2011;3-7.

8. Oloyede G K, Onocha P A, Olaniran B B. Phytochemical Toxicity, Antimicrobial and Antioxidant Screening of Leaf Extract of Peperomia pellucida from Nigeria. Adv. Environ. Biol. 2011;5(12):3700-9.

9. Sheikh H, Sikder S, Paul S K, Hasan A M R, Rahaman M M, Kundu S P. Hypoglycemic, Anti-Inflammatory and Analgesic Activity of Peperomea pellucida L. HBK (Piperaceae). International Journal of Pharmaceutical Sciences and Research. 20131;4(1):458-63

10. Nwokocha C R, Owu D U, Kinlocke K, Murray J, Delgoda R, Thaxter K, et al. Possible Mechanism of Action of the Hypotensive Effect of Peperomia pellucida and Interactions between Human Cytochrome P450 Enzymes. Med Aromat Plants. 2012;1(4):1-5. https://doi.org/10.4172/2167-0412.1000105.

11. Saputri F C, Mun'im A, Lukmanto D, Aisyah S N, Rinandy J S. Inhibition of Angiotensin Converting Enzyme (ACE) Activity by Some Indonesia Edible Plants. International Journal of Pharmaceutical Sciences and Research. 2015;6(3):10549 .

12. Alothman M, Bhat R, Karim A A. Effect of Radiation Processing on Phytochemicals and Antioxidants in Plant Produce. Trends in Food Science and Technology. 2009;20:201-12 https://doi.org/10.1016/j.tifs.2009.02.003.

13. IAEA. 2010. Radiation Biology: A Handbook for Teachers and Students. IAEA, Vienna, Austria.

14. Aquino K A, Sterilization by Gamma Irradiation, Prof. Feriz Adrovic (Ed.). 2012. Federal University of Pernambuco-Department of Nuclear Energy: InTech.

15. Musa KH, Abdullah A, Al-Haiqi A. Determination of DPPH free radical scavenging activity: Application of artifical neural network. Food Chemistry. 2015;194:70511. https://doi.org/10.1016/j.foodchem.2015.08.038 PMid:26471610.

16. Harrison K, Were L M. Effect of gamma irradiation on total phenolic content yield and antioxidant capacity of Almond skin extracts, Food Chemistry. 2007;102:932-7. https://doi.org/10.1016/j.foodchem.2006.06.034.

17. Pinela J, Barros L, Antonio AL, Carvalho AM, Oliveira MBPP, Ferriera ICFR, Quality Control of Gamma Irradiated Dwarf Mallow (Malva neglecta Wallr.) Based on Color, Organic Acids, Total Phenolics and Antioxidant Parameters. 
Molecules, 2016;21(4):467-80. https://doi.org/10.3390/molecules21040467 PMid:27070569

18. Oms-Oliu G, Odriozola-Serrano I, Martín-Belloso O, The Effects of Non-Therma Technologies on Phytochemicals. In V. Rao (Ed.), Phytochemicals - A Global Perspective of Their Role in Nutrition and Health. 2012; pp. 107-26 Spanyol: InTech.

19. Lee JW, Kim J K, Srinivasan P, Choi J, Kim J H, Han S B., et al. Effect of gamma irradiation on microbial analysis, antioxidant activity, sugar content and color of ready-to-use tamarind juice during storage. LWT-Food Science and Technology. 2008;42:101-5. https://doi.org/10.1016/j.Iwt.2008.06.004.

20. Hussein S, Ling APK, Lau CY, Ong SL, Harun AR. Morphological and Biochemi- cal Response of Eurycoma longifolia Callus to Gamma Irradiation. Bioremediation, Biodiversity, and Bioavability. 2012;6(1):70-4.

21. Abdeldaiem MH, Hoda GMA, Nasr EH, Antioxidant activity of extract from gamma irradiated red grape (Vitis vinifera) seeds, Journal of Radiation Research and Applied Sciences. 2012;5(2):221-42.

22. Isabella E, Pohan T, Formulation of Oil-in-Water Cream from Mangosteen (Garcinia mangostana L.) Pericarp Extract Preserved by Gamma Irradiation, Atom Indonesia. 2013;39(3):136-44. https://doi.org/10.17146/aii.2013.256.

23. Harborne JB, Phytochemical Methods - A Guide to Modern Techniques Of Plant Analysis (2nd ed.), 1984, London: Chapman and Hall. PMCid:PMC1193218.
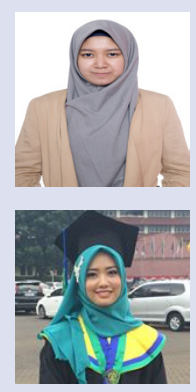

Alisa Nur Octaviani: Completed Bachelor of Pharmacy from Universitas Indonesia, Indonesia.

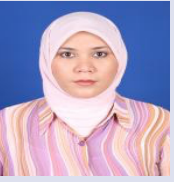

Rissyelli: Is graduated in Facult of Pharmacy Universitas Indonesia. The study focused in Natural Products. Specialization course in Dyslipidemia.

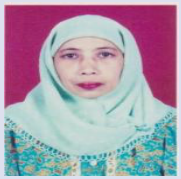

Anies Monica Adhitia: Completed Bachelor of Pharmacy from Universitas Indonesia, Indonesia. Her practice interests are in pain management pharmacotherapy, medication-taking behaviors, and patient-reported outcomes

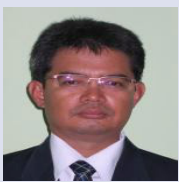

Katrin Basah: Is graduate in School of Pharmacy, Bandung Institute of Technology, in the discipline of Natural products. Specialization in Pharmacognosy of Indonesia Traditional Medicine.

Abdul Mun'im: Completed his PhD degree at Institute of Applied Biochemistry, University of Tsukuba, Japan. Currently, he focused his research on Indonesia's traditional medicinal plants for anti-metabolic syndrome, such anti-diabetes, anti-dyslipidemia, and anti-hypertension, via inhibition of angiotensin converting enzyme activity.

Cite this Article: Adhitia AM, Octaviani AN, Rissyelly, Basah K, Mun'im A. Effect of Gamma Irradiation on Angiotensin Converting Enzyme Inhibition, Antioxidant Activity, Total Phenolic Compound and Total Flavonoid of Peperomia pellucida Herbs Extract. Pharmacogn J. 2017;9(2):244-8. 